\title{
Optimization Transportation Problem Using Generalized Unified Tabu Search: A Study on Ginger Distributions in Java, Indonesia
}

\author{
Wijanarko, O.M ${ }^{1}$ and Ertiningsih, $\mathrm{D}^{2, *}$ \\ ${ }^{1,2}$ Department of Mathematics, Faculty of Mathematics and Natural Sciences, Universitas Gadjah Mada, \\ Yogyakarta, Indonesia \\ *Corresponding author. Email: dwi_ertiningsih@ugm.ac.id
}

\begin{abstract}
In a minimization problem, there are some operational costs, such as transportation costs which are not negligible. In this research we discuss a transportation problem and propose a comparison of the generalized unified tabu search and the branch and bound algorithms. One of our concerns is the geographical condition of Indonesia, which is an archipelago country. To minimize these costs, the decision maker needs to determine the best route. In a distribution cycle, the goods from the supplier are picked up by the transporter and then sent to the processing factory. Several issues were highlighted in the actual process of designing contracts such as the use of historical data. In determining the route, an approach based on scenario analysis is used which consists of revising the steps and information. In this case, the generalized unified tabu search algorithm is used to find the best route and its performance is compared using the branch and bound method. As a numerical simulation, this research is applied on ginger distributions in Java, Indonesia.
\end{abstract}

Keywords: tabu search, multi depot periodic vehicle routing problem, generalized unified tabu search

\section{INTRODUCTION}

Over the years, technology has revolutionized our world and daily lives. Technology has also given us brand new devices in recent decades, like smartwatches, tablets, and voice assistant devices. With these devices, we can do things like transfer money instantly and make purchases for everything from clothes, food delivery, groceries, furniture, and more. It makes shopping easier so that people become consumptive. To fulfill the demand, the number of productions will be increased. In the production process, business actors need raw materials. To maximize the profit, business actors should buy raw materials from first hand suppliers.

Indonesia is an archipelago country with an area of approximately 9 million $\mathrm{km}^{2}$ which is located between two oceans and two continents with a total of 17,500 islands with a coastline of about 95,181 km [3]. Indonesia's geographical condition as an archipelago country implies that operational cost, particularly transportation cost, should be considered. In a distribution cycle, a business actor has a contract with a group of suppliers who supply raw material on a regular (but not necessarily daily) basis to the plant. The goods from the supplier are picked up by the transporter and then sent to the factory.

The multi depot vehicle routing problem is a problem of designing, for a homogeneous vehicle fleet of capacity $\mathrm{Q}$, a set of routes for each day of a given $\ell$ day period [5]. Several issues were highlighted in the actual process of designing contracts such as the use of historical data. In determining the routes, an approach based on scenario analysis is used which consists of revising the steps and information [4].

In 2020, approximately 179 million kilograms of ginger were produced in Indonesia. The provinces that produced the most ginger include East Java, West Java as well as Central Java [1]. Besides, there are a lot of herbal products that contain ginger. From the beginning of the outbreak of Covid-19, ginger became popular as one of the ingredients to increase the body's immune system. A lot of people hunt products made from ginger [6]. Because of increasing demand, 
business actors must increase the production of ginger. As mentioned earlier that transportation cost in Indonesia is not negligible, a generalized unified tabu search algorithm is applied to find the best route [4]. Further, the performance's result is compared with the branch and bound algorithm [8][9].

\section{METHODS}

In this research, we will discuss a vehicle routing problem, particularly a study on ginger distribution in Java, Indonesia. The Sub-Directorate of Medicinal Plants, Ministry of Agriculture, Indonesia launched an official website, called SITOBA (http://horti.pertanian.go.id/sitoba/page/index/tentangkami). Based on the Decree of the Minister of Agriculture Number 141/Kpts/HK 150/M/2/2019 concerning Types of Commodity Plants Under the Scope of the Ministry of Agriculture, medicinal plants are one of the types of plants that are under the guidance of the Directorate General of Horticulture. Currently, medicinal plant commodities that are prioritized to be developed are Ginger, Turmeric and Cardamom.

One of the menus in the SITOBA Web is SITOBA's map that can be used to search the location of ginger farmers. There are some Ginger-producing areas in Java, such as Kebumen, Sragen, Magelang, Tegal, Wonogiri, Cilacap, Pati, Karanganyar, Blora, Cianjur, Garut, Kuningan, Majalengka, Sukabumi and Bandung. In addition to SITOBA's map, Google Maps provides the distance between nodes [7]. Next, the data of farms, depots and plants for the numerical simulation is given in Table 1 below.

\begin{tabular}{|c|l|c|c|l|}
\hline No & Type & $\begin{array}{c}\text { Supply/ } \\
\text { Demand } \\
(\mathrm{kg})\end{array}$ & Day & \multicolumn{1}{|c|}{$\begin{array}{c}\text { Address (Village, } \\
\text { District) }\end{array}$} \\
\hline 1 & Farm & 144 & 1 & Kebumen, Kebumen \\
\hline 2 & Farm & 126 & 2 & Pendem, Sragen \\
\hline 3 & Farm & 192 & 2 & Depok, Magelang \\
\hline 4 & Farm & 116 & 1 & Adiwerna, Tegal \\
\hline 5 & Farm & 127 & 1 & Bulusulur, Wonogiri \\
\hline 6 & Farm & 156 & 1 & Bajing, Cilacap \\
\hline 7 & Farm & 137 & 2 & Pasucen, Pati \\
\hline 8 & Farm & 158 & 1 & Jati, Karanganyar \\
\hline 9 & Farm & 138 & 2 & Kejiwan, Wonosobo \\
\hline 10 & Farm & 153 & 1 & Tinapan, Blora \\
\hline
\end{tabular}

\begin{tabular}{|c|c|c|c|c|}
\hline 11 & Farm & 156 & 2 & Ujungmanik, Cilacap \\
\hline 12 & Farm & 133 & 1 & Limbangan, Cilacap \\
\hline 13 & Farm & 121 & 1 & Malabar, Cilacap \\
\hline 14 & Farm & 104 & 1 & $\begin{array}{l}\text { Kesugihan Kidul, } \\
\text { Cilacap }\end{array}$ \\
\hline 15 & Farm & 105 & 1 & Bulupayung, Cilacap \\
\hline 16 & Farm & 109 & 2 & Planjan, Cilacap \\
\hline 17 & Farm & 145 & 1 & Ujungmanik, Cilacap \\
\hline 18 & Farm & 140 & 2 & Pucung, Wonogiri \\
\hline 19 & Farm & 121 & 1 & Semagar, Wonogiri \\
\hline 20 & Farm & 150 & 1 & Semagar, Wonogiri \\
\hline 21 & Farm & 131 & 2 & $\begin{array}{l}\text { Genengan, } \\
\text { Karanganyar }\end{array}$ \\
\hline 22 & Farm & 144 & 1 & Nagrak, Cianjur \\
\hline 23 & Farm & 126 & 2 & Cikletik, Cianjur \\
\hline 24 & Farm & 192 & 2 & Cinta Asih, Cianjur \\
\hline 25 & Farm & 116 & 1 & Cikahuripan, Cianjur \\
\hline 26 & Farm & 127 & 1 & Hegarmanah, Cianjur \\
\hline 27 & Farm & 156 & 1 & Simpang, Cianjur \\
\hline 28 & Farm & 137 & 2 & Karyamukti, Cianjur \\
\hline 29 & Farm & 158 & 1 & Cibanteng, Cianjur \\
\hline 30 & Farm & 138 & 2 & Cibeureucem, Cianjur \\
\hline 31 & Farm & 153 & 1 & Cibuntu, Garut \\
\hline 32 & Farm & 156 & 2 & Sudalarang, Garut \\
\hline 33 & Farm & 133 & 1 & Pasanggrahan, Garut \\
\hline 34 & Farm & 121 & 1 & Sindangprabu, Garut \\
\hline 35 & Farm & 104 & 1 & Mekarwangi, Garut \\
\hline 36 & Farm & 105 & 1 & Mulakeudeu, Garut \\
\hline 37 & Farm & 109 & 2 & Ngamplang, Garut \\
\hline 38 & Farm & 145 & 1 & Bungur Beres, \\
\hline
\end{tabular}




\begin{tabular}{|c|c|c|c|c|}
\hline & & & & Kuningan \\
\hline 39 & Farm & 140 & 2 & Jalatrang, Kuningan \\
\hline 40 & Farm & 121 & 1 & $\begin{array}{l}\text { Mandapajaya, } \\
\text { Kuningan }\end{array}$ \\
\hline 41 & Farm & 150 & 1 & $\begin{array}{l}\text { Longkewang, } \\
\text { Kuningan }\end{array}$ \\
\hline 42 & Farm & 131 & 2 & $\begin{array}{l}\text { Bangunjaya, } \\
\text { Kuningan }\end{array}$ \\
\hline 43 & Farm & 144 & 1 & Situ Gede, Kuningan \\
\hline 44 & Farm & 126 & 2 & Subang, Kuningan \\
\hline 45 & Farm & 192 & 2 & Pamulihan, Kuningan \\
\hline 46 & Farm & 116 & 1 & Cihaur, Majalengka \\
\hline 47 & Farm & 127 & 1 & Pani, Majalengka \\
\hline 48 & Farm & 156 & 1 & $\begin{array}{l}\text { Tegal Sari, } \\
\text { Majalengka }\end{array}$ \\
\hline 49 & Farm & 137 & 2 & Cipicung, Majalengka \\
\hline 50 & Farm & 158 & 1 & Nunuk, Majalengka \\
\hline 51 & Farm & 138 & 2 & $\begin{array}{l}\text { Nagrak Selatan, } \\
\text { Sukabumi }\end{array}$ \\
\hline 52 & Farm & 112 & 2 & Sukaraja, Bandung \\
\hline 53 & Depot & - & - & Jering Kidul, Boyolali \\
\hline 54 & Depot & - & - & Kadipiro, Surakarta \\
\hline 55 & Plant & 3466 & - & $\begin{array}{l}\text { Jl. Raya Solo-Sragen } \\
\mathrm{Km} 7\end{array}$ \\
\hline 56 & Plant & 3664 & - & $\begin{array}{l}\text { Tlogomulyo, } \\
\text { Pedurungan }\end{array}$ \\
\hline
\end{tabular}

Table 1. Data of Farms, Depots, and Plants

The $1^{\text {st }}$ till $52^{\text {th }}$ rows in Table 1 represent the farm located in Java, particularly in Central Java, West Java, and Yogyakarta. The $53^{\text {th }}$ and $54^{\text {th }}$ rows represent the depot in Boyolali and Surakarta, respectively. Then, the $55^{\text {th }}$ and $56^{\text {th }}$ rows represent the plant that is located in Surakarta and Semarang that can receive $3466 \mathrm{~kg}$ and $3664 \mathrm{~kg}$ of ginger, respectively. Besides, the capacity (ton) and utilization $\rho(\%)$ of the vehicle is 1000 ton and $96.2 \%$, respectively.
Distribution of supply and demand in the province of Java, Indonesia is given in Figure 1. Picture 1 in the bottom of Figure 1 is a scatter plot from coordinate points $(x, y)$ of central point (blue), depot (green), farm (black), and plant (red). The problem of transporting the ginger from origin to destination at a minimal cost can be formulated as a multi depot periodic vehicle routing problem. It is referred to as the dairy transportation problem (DTP). DTP is a special case of vehicle routing problem that consists of determining the best routes to be performed for collecting ginger from farms and delivering it to processing plants [4].

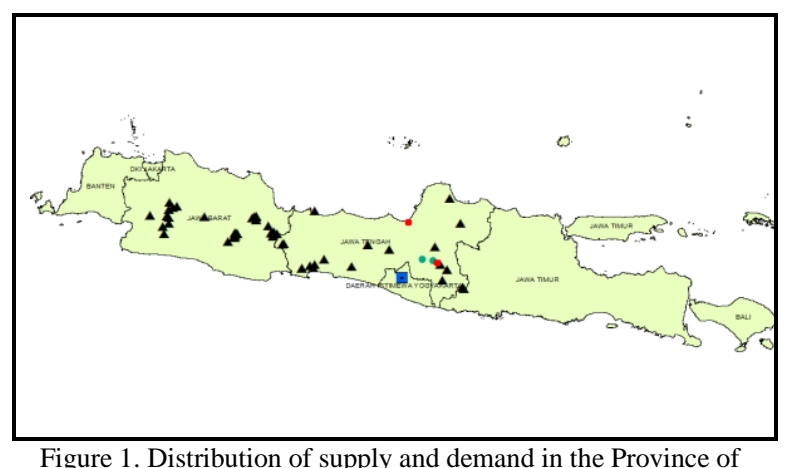

Figure 1. Distribution of supply and demand in the Province of Java, Indonesia (source: Data DEMNAS Indonesia)

Every contract with a transporter involves some route that consists of a depot, farms, plant and day service. The aim of this contract is to determine the operational cost of business actors. To generate these costs, routes are constructed to determine the collection of ginger from the farm and delivery to the processing plant. Figure 2 shows the route types. It is used to generate the transportation cost. Each route consists of a depot $d$, a sequence of collection points $f_{1}, f_{2}, \ldots, f_{n}$, and a delivery point $p$. The vehicle always returns to the depot.

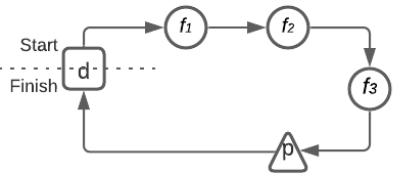

Figure 2. Route that used to generate the transportation cost

The following is a definition of a graph that will represent the routes.

Definition 1. [2] A graph, denoted by $G=(V, E)$, which consists of two finite sets $V$ and $E$. The set $V$ is not an empty set and its elements are called vertices, while the elements of the set $E$ are called edges, such that each edge connects two vertices, which is called the edge vertex.

Let $G=(V, A)$ be a graph where $V=V^{D} \cup V \cup V$, $V^{D}$ represents the set of depots, $V^{F}$ represents the set of 
farm and $V^{P}$ represents the set of plants. $|V|=d+n+$ $r$, where $d=\left|V^{D}\right|, n=\left|V^{F}\right|$, dan $r=\left|V^{P}\right|$. Each depot $o$ $\in V^{P}$ hosts a different number of vehicles $\mathrm{m}_{0}$. Let $Q_{k o}$ be the physical capacity of vehicle $k$ in depot $o$. To minimize damage, the vehicles are not fully utilized, and the utilization limit $\rho$ is introduced to bound the capacity. Each vertex $i \in V$ represents a farm requiring the collection of $\mathrm{q}_{\mathrm{i}} \mathrm{kg}$ of ginger. Each farm $f_{i}$ requires visits during the period. $L_{i}$ is a possible visitcombination. The binary constant $a_{p l}$ be equal to 1 if day $l$ belongs to visit combination $p$, and 0 otherwise. $\tau_{\mathrm{i}}$ is the time required to collect the ginger at each farm. Arc $a_{i j} \in A$ represents a direct link from vertex $i$ to vertex $j$, with the specifications of the road network and the following restrictions:

1. an empty vehicle leaving the depot cannot travel directly to a plant $\left(i \in V^{D}\right.$ and $j \in V^{P}$ then $\left.a_{i j} \notin A\right)$;

2. a vehicle must make a delivery before returning to the depot $\left(i \in V^{F}\right.$ and $j \in V^{D}$ then $\left.a_{i j} \notin A\right)$;

3. alternation between collection and delivery is prohibited $\left(i \in V^{P}\right.$ and $j \in V^{F}$ then $\left.a_{i j} \notin A\right)$.

Arc $a_{i j}$ is assigned as cost $c_{i j}$ that represents the transportation cost. The set $A$ takes into account that farms prefer collection earlier before delivery to plant. In this case, no collecting is allowed after a delivery. We use total distance in kilometers to estimate the transportation cost. In this paper, the Dairy Transportation Problem can be formulated as an integer linear programming, see [4].

In this research, we assume that there are 2 depots, 52 farms, 2 plants, 10 vehicles and 2 days service. The set of depots $V^{D}=\left\{d_{i} \mid i=1,2\right\}$, the set of farmer $V^{F}=\left\{f_{i} \mid\right.$ $i=1, \ldots, 52\}$, the set of plants $V^{P}=\left\{p_{i} \mid i=1,2\right\}$. So, $V=$ $V^{D} \cup V \cup V^{P}$. This problem can be formulated as a multi depot vehicle routing problem as follows:

$$
\text { Minimize } \sum_{i \in V} \sum_{j \in V} \sum_{k=1}^{10} \sum_{l=1}^{2} \sum_{o \in V^{D}} c_{i j} x_{i j k l o}
$$

subject to

$$
\begin{aligned}
& \sum_{p \in L_{i}} \sum_{o \in V^{D}} y_{i p o}=1, i \in V^{F} \\
& \sum_{j \in V} \sum_{k=1}^{10} x_{i j k l o}-\sum_{p \in L_{i}} a_{p l} y_{i p o}=0, i \in V^{F} ; o \in V^{D} ; l=1,2
\end{aligned}
$$$$
\sum_{j \in V^{F} \cup V^{P}} \mathrm{x}_{0 j k l o} \leq 1, o a \in V^{D} ; k=1,2, \ldots, 10 ; l=1,2
$$$$
\sum_{j \in V^{F} \cup V^{P}} x_{i j k l o}=0, i, o \in V^{D} ; i \neq o ; k=1, \ldots, 10 ; l=1,2
$$

$$
\sum_{j \in V} x_{j i k l o}-\sum_{j \in V} x_{i j k l o}=0, i, o \in V^{D} ; k=1, \ldots, 10 ; l=1,2
$$

$\sum_{i \in V^{D} \cup V^{F}} \sum_{j \in V} q_{i} x_{i j k l o} \leq \rho Q_{k o}, o \in V^{D} ; k=1, \ldots, 10 ; l=1,2$

$\sum_{i \in V} \sum_{j \in V}\left(c_{i j}+\tau_{i}\right) x_{i j k l o} \leq T, o \in V^{D} ; k=1, \ldots, 10 ; l=1,2$

$\sum_{i \in V^{D} \cup V^{F}} \sum_{k=1}^{10} \sum_{o \in V^{D}} q_{i} x_{i j k l o} \leq Q_{j}, j \in V^{P} ; l=1,2$

$\sum_{i \in V^{D} \cup V^{F}} \sum_{k=1}^{10} \sum_{l=1}^{2} \sum_{o \in V^{D}} q_{i} x_{i j k l o} \geq D_{j}+\delta_{j}^{-}, j \in V^{P}$

$\sum_{i \in V^{D} \cup V^{F}} \sum_{k=1}^{10} \sum_{l=1}^{2} \sum_{o \in V^{D}} q_{i} x_{i j k l o} \leq D_{j}+\delta_{j}^{+}, j \in V^{P}$

$\sum_{i \in V^{P}} z_{i k l o} \leq 1, k=1, \ldots, 10 ; l=1,2 ; o \in V^{D}$

$\sum_{i \in V^{D} \cup V^{F}} x_{i j k l o}-z_{j k l o}=0, j \in V^{P} ; k=1, \ldots, 10 ; l=1,2 ; o \in V^{D}$

$\sum_{i \in S} \sum_{j \in S} x_{i j k l o} \leq|S|-1, S \in V^{F} \cup V^{P} ;|S| \geq 2 ; o \in V^{D} ;$

$k=1, \ldots, 10 ; l=1,2$

$x_{i j k l o} \in\{0,1\}, i \in V ; j \in V ; o \in V^{D} ; k=1, \ldots, 10 ; l=1,2$

$y_{i p o} \in\{0,1\}, i \in V ; p \in L_{i} ; o \in V^{D}$

$z_{i k l o} \in\{0,1\}, i \in V ; j \in V ; o \in V^{D} ; k=1, \ldots, 10 ; l=1,2$.

\section{RESULT AND DISCUSSION}

In this section we will apply two algorithms to solve the Dairy Transportation Problem (DTP), that is a Generalized Unified Tabu Search (GUTS) and branch and bound algorithms. DTP is solved as a special case of a heterogeneous multi depot vehicle routing problem with capacity and constraints where a set of collecting points and delivery destinations are defined, using GUTS algorithm [4].

GUTS algorithm is based on tabu search, a metaheuristic that explores the solution space of a problem by iteratively moving from the current solution $s$ to $s^{\prime} \in N(s)$, where $N(s)$ is the neighborhood of solution s. The local search continues until the stopping criterion is satisfied [4]. Figure 3 shows the flowchart of the GUTS algorithm. To find the solutions, we proceed as follows. For the transporters and depot, we evaluate the competition of the routes: 


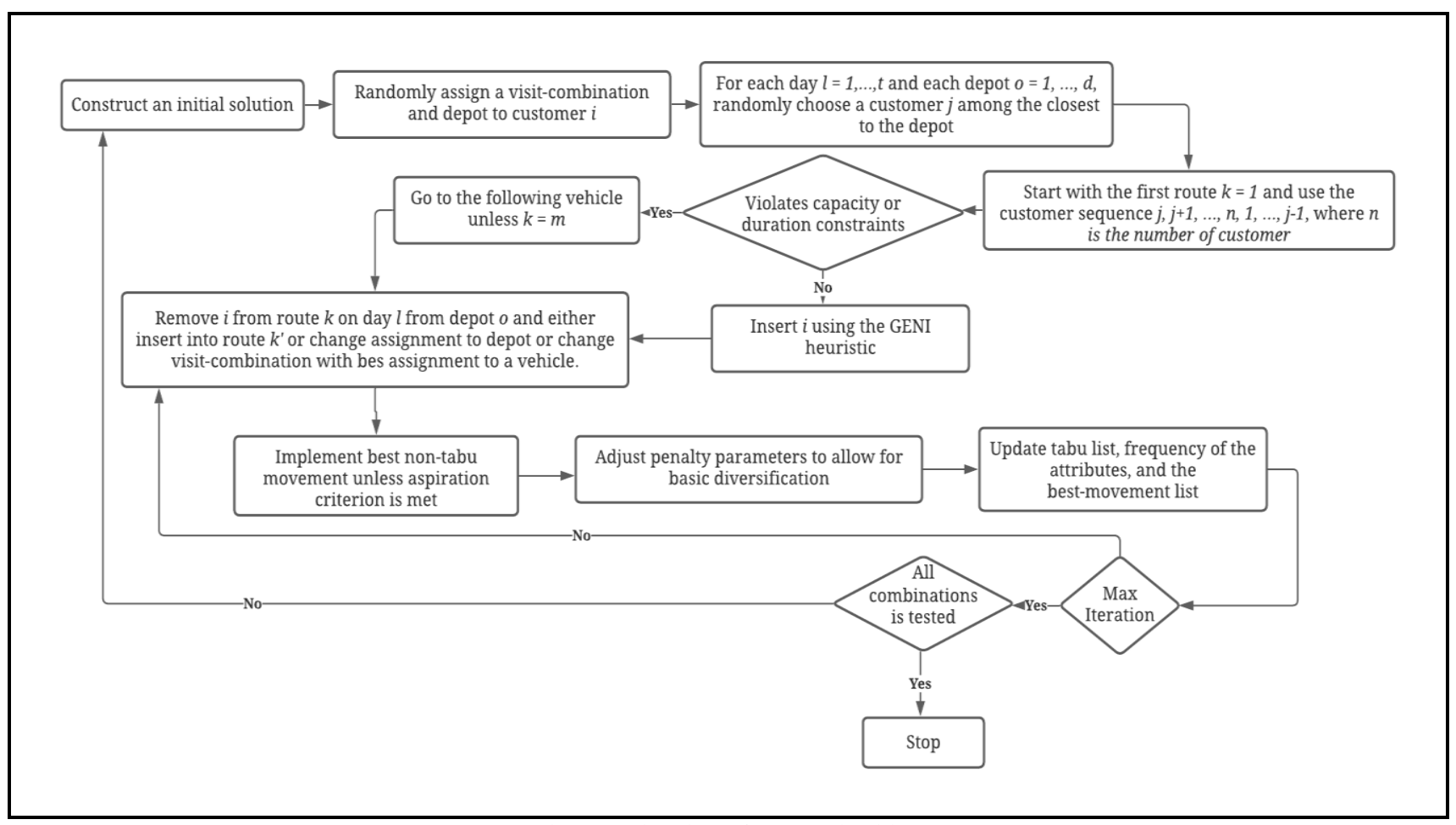

Figure 3. Flowchart of GUTS Algorithm

\begin{tabular}{|c|c|c|}
\hline Route & Path & $\begin{array}{c}\text { Distance } \\
(\mathbf{k m})\end{array}$ \\
\hline 1 & $d_{1}-f_{9}-f_{8}-f_{21}-f_{20}-f_{7}-f_{3}-p_{1}-d_{1}$ & 749.4 \\
\hline 2 & $d_{2}-f_{10}-f_{18}-f_{19}-f_{5}-f_{4}-f_{12}-f_{13}-p_{1}-d_{2}$ & 1031.2 \\
\hline 3 & $d_{1}-f_{22}-f_{25}-f_{26}-f_{27}-f_{29}-f_{31}-p_{1}-d_{1}$ & 1289.4 \\
\hline 4 & $d_{1}-f_{33}-f_{34}-f_{35}-f_{36}-f_{38}-f_{40}-f_{41}-p_{1}-d_{1}$ & 1009 \\
\hline 5 & $d_{1}-f_{43}-f_{46}-f_{47}-f_{48}-f_{50}-p_{2}-d_{1}$ & 816.3 \\
\hline 6 & $d_{1}-f_{15}-f_{14}-f_{16}-f_{6}-f_{1}-f_{2}-p_{2}-d_{1}$ & 683.4 \\
\hline 7 & $d_{1}-f_{17}-f_{11}-f_{23}-f_{24}-f_{28}-f_{30}-p_{2}-d_{1}$ & 1179 \\
\hline 8 & $d_{1}-f_{32}-f_{37}-f_{39}-f_{42}-f_{44}-f_{45}-p_{2}-d_{1}$ & 934.9 \\
\hline 9 & $d_{1}-f_{49}-f_{51}-f_{52}-p_{2}-d_{1}$ & 1181 \\
\hline & Total $(\mathrm{km})$ & 8873.6 \\
\hline
\end{tabular}

the plants, evaluate the volume received versus the demand for the plants.

For simulation, the GUTS algorithm is implemented in Python 3 and numerical simulation is run on an AMD Ryzen 3 with 2000 iterations. The best route of GUTS algorithm is given in Table 2. Route (1) - (9) is the best route for each vehicle by applying the GUTS algorithm (See Figure 4). The 10th vehicle is not used because all the farms have been visited. Further, Figure 5 depicts the best value by GUTS algorithm where the minimum total distance and the number of iterations is $8873.6 \mathrm{~km}$ and 196 , respectively.

To compare the results, a branch and bound algorithm is applied to find an optimal (local) solution of the problem. Branch and bound algorithm is implemented in Python 3, the best route as given in Table 3. Route (1) - (9) is the best route for each vehicle by applying branch and bound algorithm because it yields the minimum total distance, i.e., 9022.99 km (See Figure 6).

length, utilization of vehicles, and cost (total distance or total duration). These indicators are also classified by depot to indicate how each transporter is affected by changes to the routes. Besides, comparing the service-day assignment and the assignment to the depot for the farms, whereas for 


\begin{tabular}{|c|c|c|}
\hline Route & Path & $\begin{array}{c}\text { Distance } \\
(\mathbf{k m})\end{array}$ \\
\hline 1 & $d_{2}-f_{1}-f_{6}-f_{4}-f_{10}-f_{8}-f_{5}-p_{1}-d_{2}$ & 776.1 \\
\hline 2 & $d_{1}-f_{12}-f_{13}-f_{17}-f_{15}-f_{14}-f_{19}-f_{20}-p_{1}-d_{1}$ & 704.6 \\
\hline 3 & $d_{1}-f_{22}-f_{29}-f_{27}-f_{26}-f_{25}-f_{31}-p_{1}-d_{1}$ & 1277.2 \\
\hline 4 & $d_{1}-f_{33}-f_{34}-f_{36}-f_{35}-f_{41}-f_{38}-f_{40}-p_{1}-d_{1}$ & 952.5 \\
\hline \multirow[t]{2}{*}{5} & $d_{1}-f_{43}-f_{47}-f_{46}-f_{50}-f_{48}-p_{2}-d_{1}$ & 811 \\
\hline & $d_{2}-f_{2}-f_{7}-f_{3}-f_{16}-f_{11}-f_{9}-p_{2}-d_{2}$ & 826.19 \\
\hline 7 & $d_{2}-f_{18}-f_{23}-f_{30}-f_{24}-f_{28}-f_{21}-p_{2}-d_{2}$ & 1579 \\
\hline 8 & $d_{1}-f_{32}-f_{37}-f_{42}-f_{45}-f_{44}-f_{39}-p_{2}-d_{1}$ & 915.4 \\
\hline 9 & $d_{1}-f_{49}-f_{51}-f_{52}-p_{2}-d_{1}$ & 1181 \\
\hline \multicolumn{2}{|c|}{ Total $(\mathrm{km})$} & 9022.99 \\
\hline
\end{tabular}

Table 3. Route, Path, and Distance for each Vehicles by Branch and Bound Algorithm
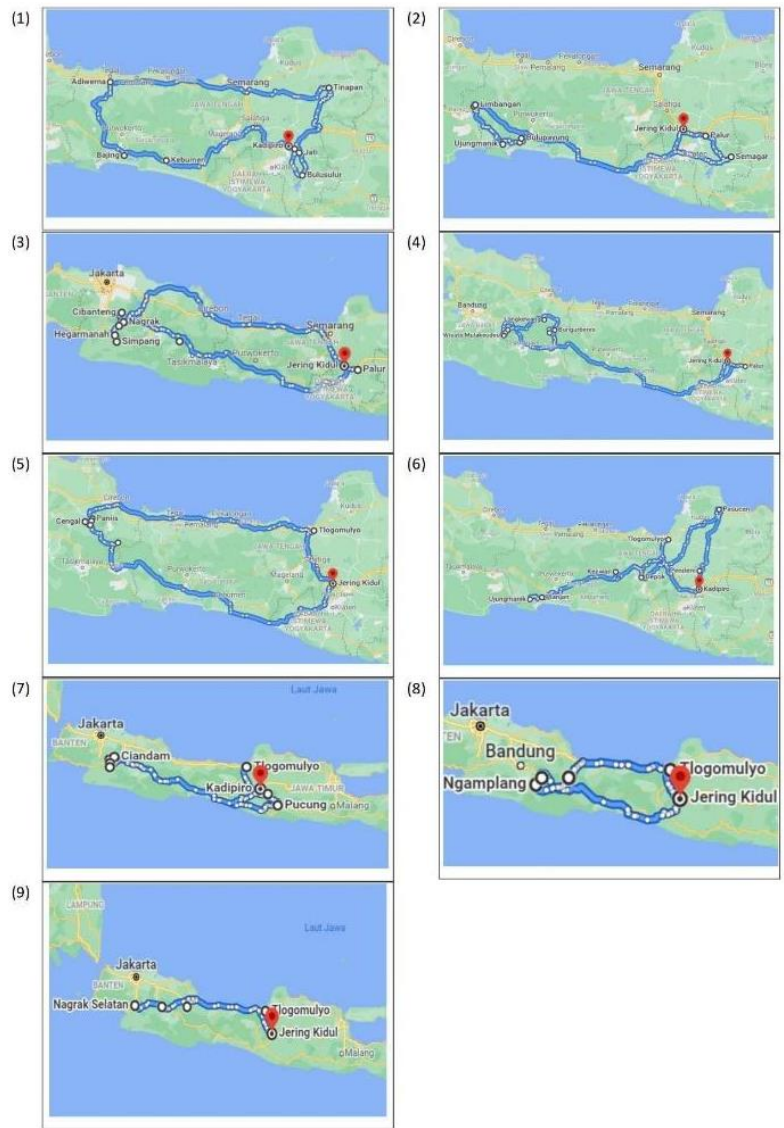

Figure 5. Best Value of GUTS Algorithm
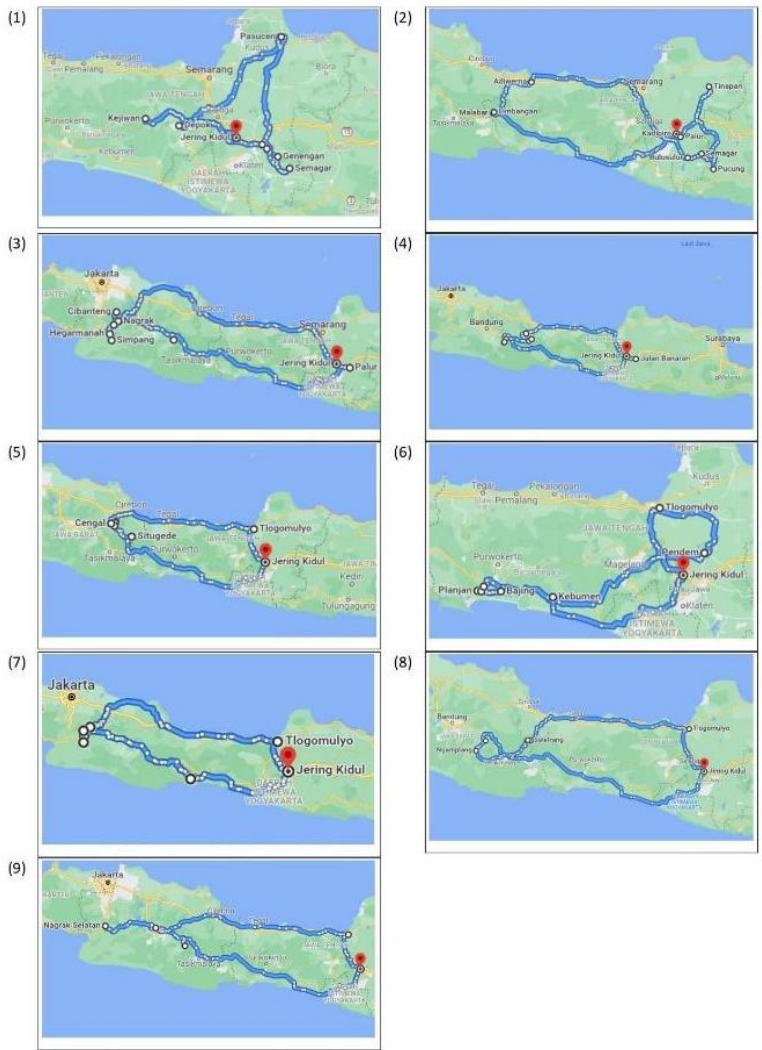

Figure 4. Best Route for each Vehicle by Applying GUTS Algorithm

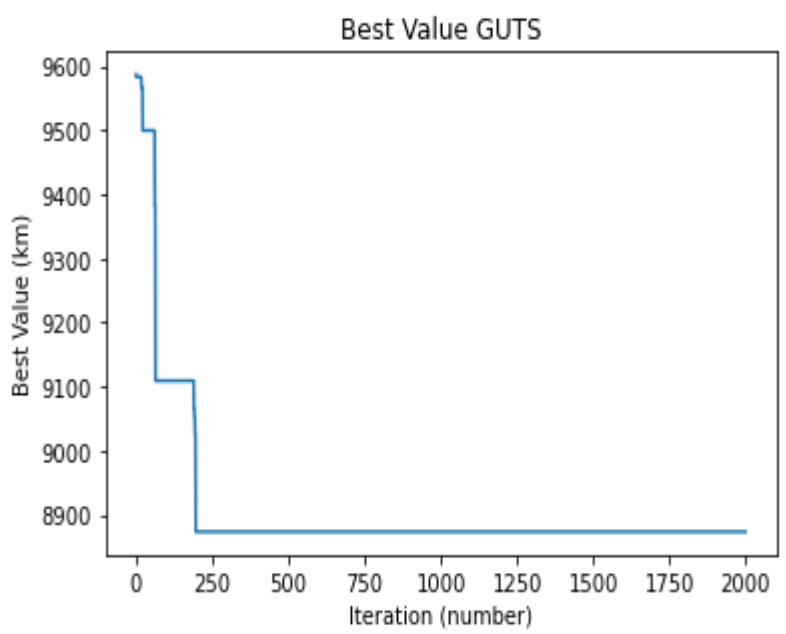

Figure 6. Best Route for each Vehicle by Applying Branch and Bound Algorithm

From both results, it shows that for ginger distribution in Java, the performance of the GUTS algorithm is better than the branch and bound algorithm. That is, the minimum total distance travelled by applying GUTS and branch-andbound algorithms are $8873.6 \mathrm{~km}$ and $9022.99 \mathrm{~km}$, respectively. Based on the best route results, there are only 9 effective vehicles, whereas 1 vehicle does not need to be operated because all the farms have been visited by 9 other operated vehicles. 


\section{CONCLUSION}

In this paper we have studied a dairy transportation problem on ginger distributions in Java, Indonesia. To solve this problem in a highly constrained environment, the decision maker usually uses the previous assignments to transporters, days, plants, and farms to determine each year how the ginger will be routed. Each route specifies the depot, the vehicle, the day, the set of farms, the order in which the collection should be performed, and the processing plant. In this paper, the generalized unified tabu search algorithm is used to find the best route and its performance is compared to the branch and bound algorithm. It can be concluded that the performance of the GUTS algorithm is better than the branch and bound algorithm on ginger distributions in Central Java, Indonesia.

\section{ACKNOWLEDGMENT}

This research is financially supported by UGM through the Rekognisi Tugas Akhir (RTA) 2021 programme.

\section{REFERENCES}

[1] Anonim, Production of ginger in Indonesia from 2011 to 2020, Statista Research Department, 2021. Accessed Tuesday, 14 September 2021 in

https://www.statista.com/statistics/706466/production-ofginger-in-indonesia/.

[2] Gross, J.L. and Yellen, J., Graph Theory and Its Applications, Chapman \& Hall/CRC, 2006.

[3] Kusmana, C. and Hikmat, A., Keanekaragaman Hayati Flora di Indonesia, Bogor, Jurnal Pengelolaan Sumberdaya Alam dan Lingkungan, 2015, vol 5 no 2: 187-198.

[4] Lahrichi, N., Crainic T. G., Gendreau, M., Rei, W. and Rousseau L.M.,Strategic analysis of the dairy transportation problem, Journal of the Operational Research Society, 2015, 66. 44-56.

[5] Mingozzi, A., The Multi-depot Periodic Vehicle Routing Problem, Abstraction, Reformulation and Approximation, 2005, pp 347-350.

[6] Spiller, S., Price of ginger skyrockets as Covid-19 propels demand, 2021, Accessed Tuesday, 14 September 2021 in

https://www.iol.co.za/weekend-argus/news/price-ofginger-skyrockets-as-covid-19-propels-demandf46327ba-769a-46cb-a58d-ef7c7dcf274f.

[7] Sub-Directorate of Medicinal Plants, Ministry of Agriculture, Indonesia, Peta Sentra dan Kelompok Tani Jahe, Kunyit, Kapulaga, SITOBA. Accessed Tuesday, 10 August 2021 in http://horti.pertanian.go.id/sitoba/peta.

[8] Taha, H. A., Operation Research an Introduction, Prentice-Hall, Pte Ltd, Singapore, 1998.

[9] Winston, W.L., Operation Research Application and Algorithms, Ruxbury Press, 2004. 